\title{
Understanding Impact Sustainable Intention of S-Commerce Activities: The Role of Customer Experiences, Perceived Value, and Mediation of Relationship Quality
}

\author{
Untung Rahardja ${ }^{1}$, Tanaporn Hongsuchon ${ }^{2, *}$, Taqwa Hariguna ${ }^{3, *}\left(\mathbb{D}\right.$ and Athapol Ruangkanjanases ${ }^{2, *(1)}$ \\ 1 Science and Technology Faculty, University of Raharja, Tangerang 15117, Indonesia; untung@raharja.info \\ 2 Chulalongkorn Business School, Chulalongkorn University, 254 Phayathai Road, Pathumwan, \\ Bangkok 10330, Thailand \\ 3 Departement of Information System, Universitas Amikom Purwokerto, Jl. Letjen Pol Sumarto, \\ Purwokerto Utara 53127, Jawa Tengah, Indonesia \\ * Correspondence: tanaporn.h@chula.ac.th (T.H.); taqwa@amikompurwokerto.ac.id (T.H.); \\ athapol@cbs.chula.ac.th (A.R.)
}

Citation: Rahardja, U.; Hongsuchon, T.; Hariguna, T.; Ruangkanjanases, A. Understanding Impact Sustainable Intention of S-Commerce Activities: The Role of Customer Experiences, Perceived Value, and Mediation of Relationship Quality. Sustainability 2021, 13, 11492. https://doi.org/ $10.3390 /$ su132011492

Academic Editors: Joanna Paliszkiewicz, Marcin Ratajczak and Francisco José Liébana-Cabanilla

Received: 15 August 2021

Accepted: 15 October 2021

Published: 18 October 2021

Publisher's Note: MDPI stays neutral with regard to jurisdictional claims in published maps and institutional affiliations.

Copyright: (c) 2021 by the authors. Licensee MDPI, Basel, Switzerland. This article is an open access article distributed under the terms and conditions of the Creative Commons Attribution (CC BY) license (https:/ / creativecommons.org/licenses/by/ $4.0 /)$.

\begin{abstract}
Business activities using social media are currently growing and its development has intrigued practitioners and academics. The purpose of doing this present research is to build a conceptual model, which connects the concepts of customer perceived value and customer experiences with the concept of customer relationship quality to produce sustainable customer intention in social media commerce. Considering the results of two exogenous constructions, namely customer perceived value and customer experience, it can be concluded that both have an impact on relationship quality and customer sustainable intention. In this study, there are six hypotheses, consisting of five accepted hypotheses and one rejected hypothesis. After doing a deeper analysis, it is revealed that good relationship quality determines the significance of sustainable customer intention. In addition, this conducted research examines and experimentally confirms the role of customer perceived value and the customer experience in determining relationship quality and sustainability of customers founded in social media commerce. The novelty shown in this study lies in the integration of two exogenous variables, namely customer perceived value and customer experience, with the variables of relationship quality and customer sustainability intention. Finally, the findings provide theoretical, managerial, and social value and impact for academics, practitioners, and society.
\end{abstract}

Keywords: customer perceived value; customer sustainability intention; customer relationship quality; social media commerce

\section{Introduction}

Nowadays there is a very drastic shift in physical social interaction, and some say traditional patterns of social interaction have shifted from face-to-face physical interactions to social media interactions [1]. This change is also followed by a new paradigm shift in the concept of Web 2.0 which emphasizes content, where each individual can become a content creator on their respective social media platform [2]. The presence of Facebook, Instagram, Line, YouTube, WhatsApp, and TikTok as Web 2.0 has changed business activities to be more economical and effective, and they can reach targets directly [3-5]. This has been followed by an increase in existing information technology, such as internet connections and smartphones, the use of which is increasing as a consequence of the Covid-19 pandemic. Social media has been used by many people to start a business, distribute information and promotional media to the wider community. Social media has changed the pattern of distribution of information that is disseminated through the Internet and is considered more effective in reaching all levels of society. At this time, there are a lot of social media 
that present information content that is a reference both nationally and internationally. In addition, many people also use it for positive things such as writing in personal accounts, doing business, education, and others. This is done by both experienced people and beginners, all of whom can provide varied information for public consumption. Hence, social media usage in business activities is a topic deserving of further discussion.

Not only is social media changing conventional methods of social interaction, but social media also creates the advancement of new marketing and business methods. Every company can be more interactive with its customers, then on their official website, they add social media links. This can also be done by novice entrepreneurs to take advantage of social media in conducting business transactions. If studied more deeply, at this time the government has taken social media as the medium of communication to customers and citizens, identifying customer and citizen needs, and facilitating business-to-customer (B2C) and government-to-citizen (G2C) interaction. As a result, customers and citizens are able to deliver their personal opinions, experiences and comments that are aimed at increasing the value of a product and service, as well as determine government policies or guidelines [6,7]. From the various advantages mentioned above, social media allow companies and users to connect directly, gather like-minded people, take the user into different viewpoints and behavior, and attract the regard of the public at large [8]. Meanwhile, from a business perspective, social media not only emphasizes the commercial aspect, but also the interaction between the members of a community to influence purchase intentions and beneficial reviews [9].

Nowadays, the notion of experience-based economics has grown to be an interesting area of study [10]. The customer experience (CE) is related to the sensory, emotional, and cognitive impact created by the customer pursuing an active, participatory, and observational experience that can increase interest, motivation, and recognition, and add value to a product or service [11,12]. CE enables to be incorporated into the lives of customers and society to generate a firmly-stood perspective, or develop a good way of thinking, attracting customers' attention and leaving a favorable impression, that is producing real revenue for the company and value or stature for the government [13].

The Covid-19 pandemic has forced all business activities to change massively. Competition is not the main obstacle faced by the company, but more than that the new concepts, ways of working and the new paradigm created require companies to be more innovative and adaptive to new technologies currently available. In this milieu, companies have continually developed into virtual platforms [14]. The methods of conservative marketing tend to focus on the function, the benefits and the competition of the product, and the competitive mount of customers as well. In addition, the method and the tools are identically analytical, quantitative, and verbal. On the other hand, $\mathrm{CE}$ defines consumer context and perceived value (PV) as a flexible and measurable marketing method and tool so that it focuses on competitive advantage.

Many empirical studies taking various perspectives to examine the acceptance of social media in various environments, such as information search [15], education [16], knowledge sharing [17], equity in product brands [18], as well as text mining on voting [19] has been conducted in decades. Several relevant empirical studies have also been carried out by previous researchers, namely the technology perspective on web 2.0 and its benefits $[20,21]$, and many studies have adopted the social influence perspective $[4,9,22]$.

Related to the existence of social media and the advancement of various applications to attract users, methods of business transactions and user interactions must be identified to increase sustainable intentions (SI) towards social media commerce. The present research builds a conceptual model to analyze the matter of characterization and then predict sustainable use behavior and what factors ensure the use of social media commerce, based on their viewpoint of $C E$ and its assorted values. In addition, there is an importance of exploring and understanding their perception of PV. Furthermore, it is also important to understand how CE and PV influence social media commerce through mediator relationship quality. Therefore, the analysis is purposed to determine the sustainability of the 
factors that leads to the relationship between users or customers of social media commerce by proposing a probated model based on CE and PV.

\section{Literature Review}

\subsection{Perceived Value}

Competitive advantage can be maintained by developing PV as its main differentiating tool [23-26]. Many conducted pieces of research have shown that PV is one of the several factors that influence customer satisfaction and customer trust in marketing. In addition, other studies also prove that PV can be used as a parameter of marketing success by measuring sustainability and consumer intentions [24]. Assessing the service and product value perceived by the customer can be used as a benchmark or significance of PV [27], or in other words is the perception of plenty of the costs incurred with the benefits received by the purchaser [28]. As stated by Kim et al. [29] in his study, PV is a metric that uses the benefits perceived by customers as a benchmark for assessing a service.

Consumption value is the added value perceived by customers from a product or service [30,31]. Furthermore, that consumption value is part of a person's belief to get their value, the value is the highest part perceived by customers, where the value is obtained based on their experience of social interaction [32]. The specific study of the consumption value comes from Sheth et al. [33] and yields a particular description of the theoretical basis of PV, namely the concept of consumption value, then expanded by Sweeney and Soutar [34] with a scale that includes and is measurable regarding customer perceptions of PV. PV theory is a combination of various value theories; there are at least five mainlyused types, namely functional, social, e/motional, epistemic, and conditional [35]. PV can be interpreted as a method or benchmark in assessing customer perceptions based on psychology, which includes many things such as perceptions of products and perceptions of customers [36].

Sirdeshmukh et al. [37] argue that the good relationship that exists between the customer and the provider can be harmonious and sustainable when the customer's perception of the costs that have been spent has benefits or at least the customer is satisfied with what has been done. A concept of value is essential to ascertain customer choices and behavior concerning the sustainability of using a product. Furthermore, the concept of a value must be used wisely by the provider in terms of presenting the beneficial values of a product, by providing detailed information on the product in an informative manner, good image quality, sound quality, and appropriate digital marketing. Therefore, providers must be able to reduce the experience aspect of their customers to be able to learn in detail and prioritize the right strategies to add value to managed products and improve the quality of customer experience $[14,38]$.

Based on several definitions, it explains that the concept of experience value refers to a strong relationship resulting from the experience of customer interaction after using a product $[39,40]$, while the concept of PV is the customer's conclusion about the product based on the experience he gets. Holbrook [41] explains that PV has four basic elements that can be used as benchmarks, namely: (1) Aesthetics, is the concept of beauty in the product, how its strength is in the product design or appearance, (2) Pleasure, which represents the feelings of the customer in the product. using or carrying out certain activities, (3) customer return on investment (CROI), is the expectation of the customer for the feedback he gets after investing their funds, in the hope of getting added value, (4) service excellence (this aspect includes after-sales service, excellent service both at the time of the transaction and in digital product reviews from customers). These four categories are the basic concepts in conducting an assessment of PV, so many studies refer to these four elements as research items indicators in the field of customer behavior $[14,39]$. Aesthetics can be implemented in the form of communicative visuals and design to produce a good perception of the customer [42-44]. Companies can add an elegant and informative image, thus leaving a positive impression [39,45] and this often happens in virtual communities as a form of effort to attract the attention of customers $[46,47]$. 
Deeper CROI is an inseparable part of the customer's perception of the experience he gets, and the experience will automatically compare what he gets for what he spends, so the evaluation process will take place by itself; the principle of benefit becomes important for some people, but the impulse buying factor is quite dominant for some people [14,18]. Therefore, the advantages of the services offered are factors that influence these activities. Providers must be able to convince their customers based on their needs and customer segmentation [48].

\subsection{Customer Experience}

In the field of marketing or particularly in the field of e-business, the perception and recognition of the value of a product is the main goal that must be achieved. Positive perceptions will grow based on the values and experiences gained from customer participation in e-business transactions. This experience will result in cognitive perception called customer experience (CE) [49]. Efforts that can be used to get a positive impression of CE include utilizing tangible or intangible assets $[10,50]$. CE can be an important benchmark in determining the impact of the sustainability of the business transaction because $\mathrm{CE}$ is an outcome that arises from the psychology of the customer [6]. By using the $\mathrm{CE}$ concept, providers should be able to build strategies that are obtained from the results of identification and observation of customer behavior, so that providers can map specific market share, as well as push prices competitively [51]. The basic concept of CE developed by Schmitt [49] is used as an assessment of the correlation between customers and products, this concept involves five basic essential variables, namely sense, feeling, thinking, acting, and relating. The CE concept is currently widely used to monitor digital marketing activities. The five elements are described as follows:

(1) Sense: the part of the experience that involves the five basic human senses, which are substantively used to influence customers to encourage them to buy products or services. In a perfume selling product, for example, the sense of smell is the dominant thing for customers to decide in buying the product [52]. In s-commerce, it is certainly a big problem, because the sense of smell cannot be used, and customers rely heavily on their intuition, experience, and digital content from the product. Therefore, the role of digital content becomes very dominant.

(2) Feeling: an intuition that produces emotions that can encourage customers to act rationally. Customer convenience is a conclusion that can encourage positive resonance so that the presentation of digital content must be appropriate to the mood that can evoke customer emotions [12].

(3) Thinking: in today's s-commerce world, the customers have great influence on product sustainability; the customer's experience of a product can be expressed directly and can be seen by other customers. If the results of the review are positive, it will increase the reputation of the product, and vice versa. The concept of thinking is a critical action taken by the customer, so the provider must pay attention to it in more detail.

(4) Acting: the part of the activity that has a pattern-in s-commerce acting can be translated in the form of surfing products, comparing product prices, or product reviews. This activity can leave positive or negative perceptions, depending on customer satisfaction after carrying out the activity.

(5) Relating: is an emotional bond between the customer and the commodity or utility. Strong relating allows the creation of a wider relationship with the social community.

Although there are several studies discussing CE in areas such as the service industry $[10,53]$, the expansion of the CE concept to research and new themes is always emerging, as is the lack of integration of CE into s-commerce. The concept of CE is currently being used in many scientific discussions, especially in the field of digital marketing, digital content, and e-business, because the concept of CE is very possibly adopted in these fields. Furthermore, the CE concept accommodates assessments of effective, creative, and cognitive experiences, so that CE continues to develop and adapt to changes, where digital content currently competes in the world of marketing and business. 


\subsection{Relationship Quality}

Considering the earlier study, it is confirmed that the notion of Relationship Quality $(R Q)$ is the result of collaboration between two parties attached in one action so that it gives positive and negative perception and the conclusion of behavior as well [54,55]. Tajvidi et al. [56] in their research in marketing explain that the concept of RQ is built by performance and participation of both parties, the customers and the provider. In addition, Anastasiei and Dospinescu [57] propose that in building RQ, customer trust is needed to give a clear description of any information related to the company.

In the aim of ensuring that the bond between customer and provider runs well, $\mathrm{RQ}$ becomes the important variable to be understood and implemented [58]. Another researcher proposed that building RQ gives a positive effect and significantly builds loyalty between them [59]. It then implicates the customer intention in doing purchases [60,61]. Furthermore, another effect will give a detailed description of the possibility of customer participation in social media [62]. Therefore, $R Q$ is seen as a composite variable consisting of three main variables that relate to each other. Those three are the satisfaction variable that is used to measure the level of customer satisfaction, the trust variable to measure the level of customer trust, and the commitment variable to account for the level of customer commitment $[55,63]$. However, this study only concentrates on two constructions, namely trust and satisfaction. The reasons for this are as follows: first, many previous studies that discussed relationship quality as construction only focus on the two dimensions of trust and satisfaction [64-67]; therefore, eliminating commitment does not have a significant impact. Second, commitment is the output of the relationship concept [68] which is owned by customer loyalty [69]. In addition, some literature states that assurance is not part of the relationship quality construction [70-72].

$\mathrm{RQ}$ is a variable used as a mediator to the other variables. It is also used as a mediator to another research in social media, that is as an indicator to support sustainable intention for the customer who has been familiar with social media commerce [73]. As stated by Masri et al. [74], a determining factor to predict customer intention in doing purchase by social media e-commerce can be understood by seeing RQ activities. Furthermore, the effectiveness and quality of information systems can be measured using a variable indicator like the variable of customer satisfaction and customer trust to know more about customer intentions. Research conducted by Zhang et al. [75] confirms that good RQ between customer and provider is needed to build customer loyalty. Meanwhile, another determining variable like social norm and information system quality is needed to be adopted.

\subsection{Sustainable Intention of Social Media Commerce}

Various social media applications, including Instagram, Youtube, Facebook, Line, and others have been considered as the platforms of choice used by individuals, companies, or governments to distribute information, display works, attract comments, build opinions, and explain policies made. The reputation of social media apps owned by individuals or companies can quickly increase as a result of sharing among users. Nevertheless, the availability of empirical studies on the evaluation of S-Commerce among social media users and operators is minor. Customers usually have an attachment to a product or service when there is an emotional bond to online activities [76,77]. Emotional relationships and good communication are the two main factors in building relationships between customers and products [78]. When the emotional aspect is more dominant, there will be harmonization between the customer and the product [79]. Another study found that communication and interaction sustainability between consumers and vendors has a beneficial effect on their relationship $[78,80]$. If the customer-vendor relationship is transformed into a favorable impression of consumers towards products and services, then the establishment of satisfaction and loyalty of these consumers will run smoothly [81]. Therefore, in this study $\mathrm{S}$-Commerce is defined as a measurement of the strength of a relationship and the degree to which a relationship can meet an expectation to maintain perpetual correspondence with 
customers. From an S-Commerce perspective, the customer's interactive relationship with the provider can be regarded as a perpetual relationship. In general, with the interaction and action of sharing information about the product and reviews of the product, customers have built and confirmed their attachment to the product [82]. The emotional relationship of the customer, the assessment of the product's functionality, and the performance of the product or service are the key factors that affect the customer's relationship with the product [83]. In addition, the increase in the frequency and duration of product interactions with customers reflects the increased stability of their relationship [82]. Thus, in this study, the adopted S-Commerce is involved as a key metric of the perpetual relationship between users and operators of social media commerce. Dealing with the construct definition as we explained earlier, here is further explanation about it as it is shown in Table 1 below:

Table 1. Operation definition.

\begin{tabular}{|c|c|c|}
\hline Construct & Definition & Source \\
\hline Customer Experience (CE) & $\begin{array}{l}\text { Activities that involve the activities of s-commerce } \\
\text { users can have an emotional and cognitive impact, } \\
\text { thereby increasing interest, motivation, and } \\
\text { recognition of the performance, which in the end } \\
\text { provides a positive added value. }\end{array}$ & $\begin{array}{l}\text { Schmitt [84]; } \\
\text { Homburg et al. [85]; } \\
\text { Chen \& Lin [86] }\end{array}$ \\
\hline Relationship Quality (RQ) & $\begin{array}{l}\text { It is part of a holistic assessment of the relationship } \\
\text { between s-commerce users and providers. The main } \\
\text { focus, in this case, is the content elements provided } \\
\text { by s-commerce. Things that exist in the form of } \\
\text { emotional closeness, openness between the two } \\
\text { parties, to continuous communication. }\end{array}$ & $\begin{array}{l}\text { Crosby et al. [54]; } \\
\text { Palmatier et al. [55]; } \\
\text { Tajvidi et al. [87] }\end{array}$ \\
\hline Aesthetics & $\begin{array}{l}\text { The user's subjective perspective on the design, } \\
\text { content, and product layout in the s-commerce } \\
\text { environment, which is the domain of reactive } \\
\text { sources of intrinsic value. }\end{array}$ & $\begin{array}{l}\text { Mathwick et al. [39]; } \\
\text { Shobeiri et al. [14] }\end{array}$ \\
\hline Playfulness & $\begin{array}{l}\text { The feeling of happiness is felt by users when using } \\
\text { s-commerce as a transaction medium. One of the } \\
\text { active sources of intrinsic value }\end{array}$ & $\begin{array}{l}\text { Mathwick et al. [39]; } \\
\text { Shobeiri et al. [14] }\end{array}$ \\
\hline Consumer return on investment & $\begin{array}{l}\text { Benefits that are felt after spending money and time } \\
\text { resources during transactions with s-commerce. This } \\
\text { is a psychologically measurable benefit. ROI is part } \\
\text { of active sources of extrinsic value. }\end{array}$ & $\begin{array}{l}\text { Mathwick et al. [39]; } \\
\text { Shobeiri et al. [14] }\end{array}$ \\
\hline Service excellence & $\begin{array}{l}\text { Art of the commitment to the promised quality of } \\
\text { service. Furthermore, it is implemented to meet the } \\
\text { expectations of s-commerce users. This is part of } \\
\text { reactive sources of extrinsic value. }\end{array}$ & $\begin{array}{l}\text { Mathwick et al. [39]; } \\
\text { Shobeiri et al. [14] }\end{array}$ \\
\hline Sustainable Intention & $\begin{array}{l}\text { Routine activities carried out by users for } \\
\text { sustainable use of s-commerce. }\end{array}$ & $\begin{array}{l}\text { Bhattacherjee [88]; } \\
\text { Bhattacherjee et al. [89]; } \\
\text { Chen et al. [4]; } \\
\text { Chen et al. [90]. }\end{array}$ \\
\hline
\end{tabular}

\section{Development of Research Hypotheses}

The basic concept of $\mathrm{CE}$ is defined as the structured assessment coming from the customer so that the provider could get meaningful feedback. The assessment is displayed in the form of a matrix $[39,40]$. PV is a perception that is felt based on the experience of interacting with customers, and the results are depicted in the form of a factual assessment item. These items include the benefits of the customer experience, determined by comparing the resources that have been expended with the benefits obtained, including the advantages of good service; these advantages are determined by the strong commitment provided by service providers that can meet the expectations of customers. In addition, there is an aesthetic value, which is ascertained by subjective assessment and the privilege felt by the customer $[39,40]$. Understanding the previous research, it is explained that CE is an activity coming from customer assessment that gives the emotional result and cognitive 
effect. The score of assessment is seen as the result of participation and observation that can be taken into a consideration as an indicator to assess customer motivation and satisfaction [11,12]. Using the variable of CE, the provider could get customer impression as additional information in organizing customers in the future. They can build a positive image from the customer experiences $[13,49]$. Theoretically, CE has a strategic role in building a positive impression from the customer. Therefore, the present research proposes a hypothesis as follows.

\section{Hypothesis 1. CE has a positive and significant influence on customer PV.}

The basic concept of CE comes from the extraction of the effects of customer activity in the past. The activities give various effects; negativity and positivity depend on the result of customer evaluation; positivity as the result of customer evaluation can be defined as customer satisfaction, and impression coming from customer assessment build perception of customer trust [91,92]. The experiences are viewed by the customer, who gives objective scoring. If customer perception is positive and it tends to be beneficial, it will give good scores and vice versa. The basic concept of this assessment becomes the main variable in building customer trust and customer satisfaction. Both variables have a strong correlation in building CE [93]. If the score tends to be positive, satisfaction and trust are built for a long time [94]. It embodies an implication of customer loyalty [91,95]. It has been proven by an earlier study that the good management of CE can improve customer loyalty. This means that the satisfaction and trust variables should be well-maintained [96]. Another research focused on online games reveals that using the potential value of CE can improve the purchase of games online [97]. Thinking of that research, the conclusion can be explained by the hypothesis that CE is a model for building customer perception and it has potential in improving customer satisfaction and customer trust. If the scoring of those variables is significant, it could give impact to SI:

Hypothesis 2. CE has a positive and significant influence on customer RQ (satisfaction and trust).

Hypothesis 3. CE has a positive and significant influence on customer SI.

The literature review of the research explained that the concept of PV relates to the process of forming customer satisfaction and customer trust. Both are the component that builds customer intention, especially in the service industry [98]. In addition, the PV variable is dominantly used to measure the level of customer loyalty and it can give a positive score to customer satisfaction and customer trust [99]. Many researchers give detailed information about the PV concept that correlates with customer satisfaction $[27,100,101]$. In the software engineering and information systems industry, PV gives a positive score to customer sustainable intention as well as other variables like customer satisfaction and customer trust $[29,102]$. Thus, the present research proposes a hypothesis as follows:

Hypothesis 4. Customer PV has a positive and significant influence on customer RQ (satisfaction and trust).

Hypothesis 5. Customer PV has a positive and significant influence on customer SI.

Much research in information technology confirmed that the variable of user satisfaction and trust is used to measure user sustainable intention, and that the variables are adopted from the concept of expectation confirmation model [103]. The theory of user behavior in information technology is known as post-adoption theory. The theory states that the customer experience after sing the technology affects their perception. It could be positive or negative. Other research proves that ECM is seen as a method that has a strong correlation to user perception, especially in the level of satisfaction to use, trust in technology, and the continuity of technology usage [89,104,105]. ECM has also been 
confirmed by many researchers as having a significant relationship that can give positivity to other supporting variables like user satisfaction, user trust, and sustainable intention. User satisfaction and user trust are specifically extracted to the variable of relationship quality. In this research, relationship quality is used generally in the scope of social media commerce. If the customer is satisfied with the activity and trusts the process, it improves its sustainable intention. It leads to the hypothesis as written below.

Hypothesis 6. Customer $R Q$ (Satisfaction and trust) has a positive and significant influence on customer SI.

In principle, a brand of a product can have a strong attachment to online activities and this is a key indicator to measure the affirmation between the brand of a product and the customer [82]. However, this relationship is sometimes difficult to maintain. Maintaining the relationship between product brands and customers in online media requires a sense of satisfaction, trust, and loyalty in the long term, and consistency must always be maintained [106,107]. Furthermore, in maintaining consistency and relationships in social media commerce, we depend on quality services on an ongoing basis. To ensure that customers are satisfied with products and services, the provider must pay close attention to the basic needs of their customers, which in turn can improve their IS, make customers like the product, and have an impact on creating a stronger customer relationship with the product.

Figure 1 displays the research framework. The focus of present research lies on the use of PV and CE to explain how these two constructs affect RQ and SI in social media commerce.



Figure 1. Research framework.

\section{Research Method}

The concept applied for collecting the research data was conducting an online questionnaire using a google form, the duration of data collection was five months (February-June 2021). The respondents we surveyed were active users who had sufficient experience in conducting online transactions using social media. Quoting a survey conducted by [108] in 2021, the number of Indonesian internet users was up to 202.6 million, while the number of social media users was 170 million in January 2021. Therefore, social media users in Indonesia deserve to represent the respondents of this research. Data filtering is done to filter inexperienced s-commerce users. After collecting data, 539 data points were obtained, 
and the data was then filtered to reduce bias so there were 413 usable data points. These data were used for analysis in this study, as presented in Table 2.

Table 2. The demographic composition of the respondents.

\begin{tabular}{lcc}
\hline Characteristics & Frequency & Percent \\
\hline Respondent Gender & & \\
Male & 163 & 39.47 \\
Female & 250 & 60.53 \\
Respondent Age & & \\
$<20$ years old & 63 & 15.25 \\
21 to 30 years old & 127 & 30.75 \\
31 to 40 years old & 125 & 30.27 \\
$>40$ years old & 98 & 23.73 \\
Respondent Education & & \\
High school degree or lower & 137 & 33.17 \\
Undergraduate level & 164 & 39.71 \\
Master degree or higher & 112 & 27.12 \\
\hline
\end{tabular}

This research questionnaire was mapped into two parts in general, namely a mapping to measure the demographics of respondents, and the second mapping to measure the proposed hypothesis. The framework built in this research is an integration of several studies that have been carried out by previous researchers, as well as the question materials made based on previous references. We used seven Likert scales to assess the questionnaire items, after which the data were verified and validated [109]. Figure 1 is a framework and there were six proposed hypotheses.

\section{Data Analysis}

The concept used to analyze the data is partial least squares (PLS), while the software used in this study is Smart-PLS version 2 open access. The concrete explanations and the points of variables used are presented in Table 4 . Two stages must be carried out in this section; the first is to test the validity, then we proceed to test the reliability [110]. This study specifically examines the interaction and causality between PV, CE, RQ, and SI variables, with the items attached to each of these variables.

In choosing an analytical tool, aspects that must be considered include effectiveness, reliability, compatibility, and powerfulness. PLS has reliability in these aspects, and in terms of effectiveness PLS can perform causality analysis simultaneously for constructed models and measure items [111]. From the aspect of reliability, PLS can be used for complex data analysis [112], and so on. The framework that we propose in this research is an integration of $\mathrm{CE}, \mathrm{PV}, \mathrm{RQ}$, and SI variables, where the integration of these variables into a framework is a very complex activity. Overall, we processed 413 data in this study, proposing six relevant hypotheses that were constructed from the consideration of many preliminary studies [113]. Furthermore, grounded by those studies, we found that the CE variable is part of the formative construct $[86,114]$ so that the role of PLS in analyzing the data can be said to be superior, because, in addition to being able to perform formative analysis, PLS can simultaneously perform reflective analysis. [112,115].

PLS cannot be separated from advantages and disadvantages, as the advantages described above, PLS also has disadvantages [116], which lies in the optimization of the model parameters. So in this study, we thoroughly verify the questionnaire items used, before they are distributed to s-commerce users. Furthermore, the concept of PLS has shortcomings in testing for the fit model, so to solve this problem we use the concept of goodness of fit which is calculated conventionally. Table 3 describes the quantify items used in this study. 
Table 3. Questionnaire measurement items.

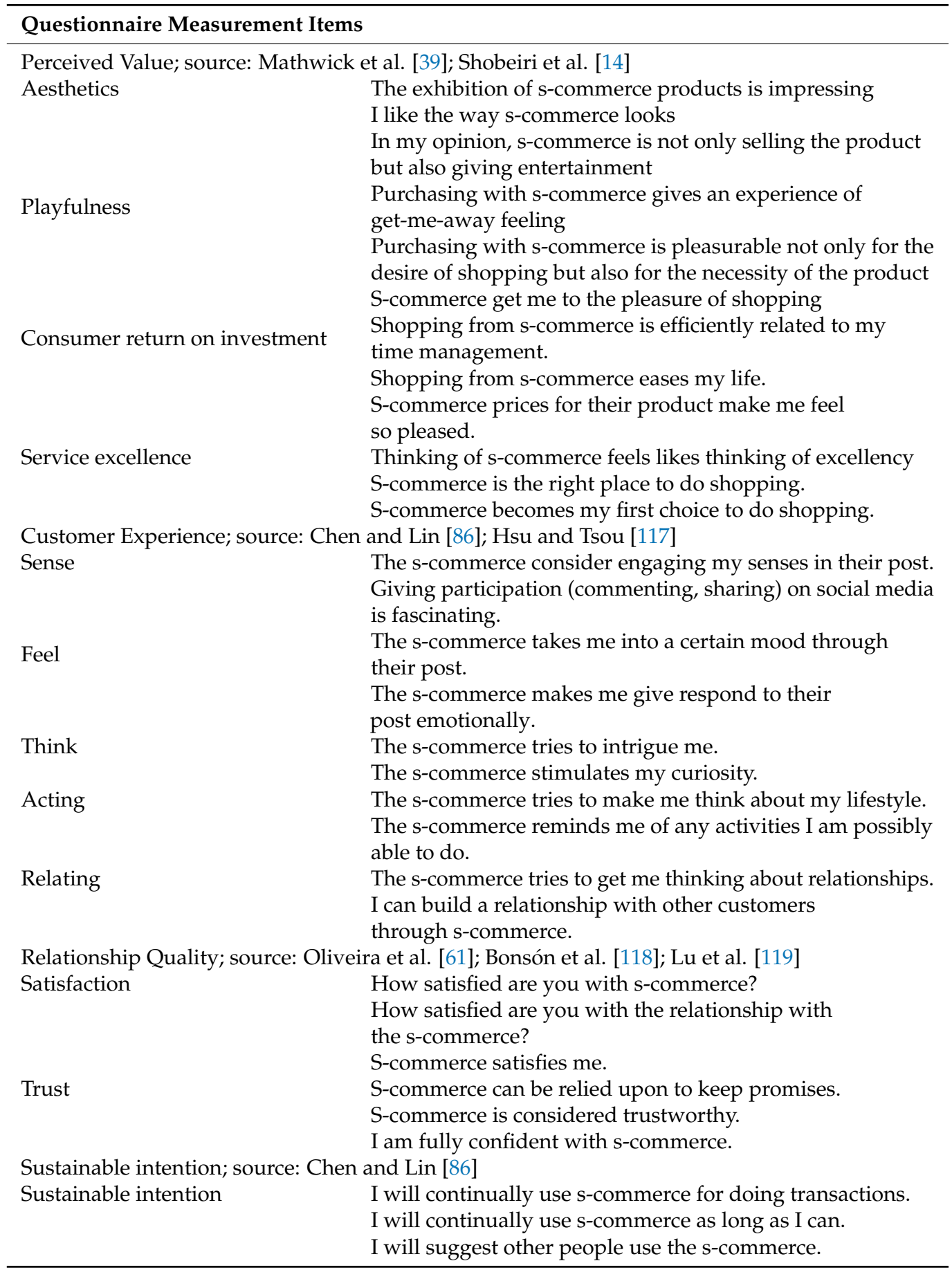

\subsection{Outer Model Verification}

To verify the construct on the outer model concept, several analyses were used consisting of reliability analysis, where the benchmark used was that the constructed value must be more than 0.7 , then convergent validity was used to measure it using the benchmarks from the loading factor value and the AVE value which must have a value higher than 0.5; the concept was taken based on Fonell and Larcker [120]. Next, discriminant validity can be found by knowing the value of the loading factor. If the value of each latent item of each construct is greater than the value of the loading factor, it can be declared to have met the standard [121]. Tables 4 and 5 show the details regarding the results of the auteur model values. In fact, from the descriptions of the tables, they have met the specified standards. 
Table 4. Reliability analysis and convergent validity.

\begin{tabular}{|c|c|c|c|c|c|}
\hline Construct & Measurement Items & $\begin{array}{c}\text { Factor } \\
\text { Loading/Coefficient } \\
\text { (t-Value) }\end{array}$ & Cronbach's Alpha & Composite Reliability & AVE \\
\hline \multirow[t]{5}{*}{ The customer experience (CE) } & SE & 0.183 & N.A & N.A & N.A \\
\hline & $\mathrm{FE}$ & 0.212 & & & \\
\hline & $\mathrm{TH}$ & 0.252 & & & \\
\hline & $\mathrm{AC}$ & 0.258 & & & \\
\hline & RE & 0.213 & & & \\
\hline \multirow{3}{*}{$\begin{array}{l}\text { Consumer return on } \\
\text { investment }(\mathrm{CRI})\end{array}$} & CRI1 & 0.846 & & & \\
\hline & CRI2 & 0.831 & 0.789 & 0.877 & 0.703 \\
\hline & CRI3 & 0.838 & & & \\
\hline \multirow[t]{3}{*}{ Aesthetics (ES) } & ES1 & 0.886 & & & \\
\hline & ES2 & 0.939 & 0.908 & 0.942 & 0.844 \\
\hline & ES3 & 0.932 & & & \\
\hline \multirow[t]{3}{*}{ Playfulness (PL) } & PL1 & 0.916 & & & \\
\hline & PL2 & 0.874 & 0.896 & 0.935 & 0.828 \\
\hline & PL3 & 0.938 & & & \\
\hline \multirow[t]{3}{*}{ Service excellent (SX) } & SX1 & 0.904 & & & \\
\hline & SX2 & 0.856 & 0.805 & 0.885 & 0.720 \\
\hline & SX3 & 0.782 & & & \\
\hline \multirow[t]{3}{*}{ Trust (TR) } & TR1 & 0.931 & & & \\
\hline & TR2 & 0.909 & 0.836 & 0.903 & 0.757 \\
\hline & TR3 & 0.761 & & & \\
\hline \multirow[t]{3}{*}{ Satisfaction (SAT) } & SAT1 & 0.807 & & & \\
\hline & SAT2 & 0.903 & 0.831 & 0.899 & 0.748 \\
\hline & SAT3 & 0.882 & & & \\
\hline \multirow[t]{3}{*}{ Sustainable Intention (SI) } & SI1 & 0.859 & & & \\
\hline & SI2 & 0.976 & 0.931 & 0.957 & 0.881 \\
\hline & SI3 & 0.976 & & & \\
\hline
\end{tabular}

Table 5. Factor loadings and cross-loadings.

\begin{tabular}{|c|c|c|c|c|c|c|c|c|c|c|c|c|}
\hline & AC & CRI & ES & FE & PL & RE & SAT & SE & SI & SX & TH & TR \\
\hline $\mathrm{AC} 1$ & 0.918 & 0.704 & 0.501 & 0.910 & 0.715 & 0.614 & 0.523 & 0.724 & 0.709 & 0.675 & 0.741 & 0.603 \\
\hline AC2 & 0.886 & 0.717 & 0.512 & 0.897 & 0.720 & 0.624 & 0.504 & 0.669 & 0.690 & 0.649 & 0.774 & 0.628 \\
\hline AC3 & 0.898 & 0.652 & 0.449 & 0.763 & 0.707 & 0.531 & 0.470 & 0.854 & 0.686 & 0.630 & 0.729 & 0.568 \\
\hline CRI1 & 0.665 & 0.846 & 0.767 & 0.608 & 0.678 & 0.889 & 0.842 & 0.592 & 0.678 & 0.904 & 0.653 & 0.790 \\
\hline CRI2 & 0.571 & 0.831 & 0.507 & 0.541 & 0.724 & 0.546 & 0.505 & 0.485 & 0.758 & 0.714 & 0.628 & 0.630 \\
\hline CRI3 & 0.692 & 0.838 & 0.551 & 0.705 & 0.807 & 0.605 & 0.529 & 0.558 & 0.798 & 0.696 & 0.800 & 0.677 \\
\hline ES1 & 0.414 & 0.574 & 0.886 & 0.383 & 0.434 & 0.735 & 0.882 & 0.413 & 0.43 & 0.674 & 0.419 & 0.732 \\
\hline ES2 & 0.502 & 0.721 & 0.939 & 0.495 & 0.597 & 0.759 & 0.780 & 0.395 & 0.593 & 0.750 & 0.566 & 0.931 \\
\hline ES3 & 0.568 & 0.716 & 0.932 & 0.538 & 0.609 & 0.769 & 0.780 & 0.482 & 0.63 & 0.752 & 0.614 & 0.909 \\
\hline FE1 & 0.918 & 0.704 & 0.501 & 0.910 & 0.715 & 0.614 & 0.523 & 0.724 & 0.709 & 0.675 & 0.741 & 0.603 \\
\hline FE2 & 0.745 & 0.550 & 0.369 & 0.882 & 0.568 & 0.504 & 0.356 & 0.647 & 0.562 & 0.471 & 0.643 & 0.454 \\
\hline FE3 & 0.886 & 0.717 & 0.512 & 0.897 & 0.720 & 0.624 & 0.504 & 0.669 & 0.690 & 0.649 & 0.774 & 0.628 \\
\hline PL1 & 0.703 & 0.771 & 0.535 & 0.641 & 0.916 & 0.596 & 0.551 & 0.589 & 0.824 & 0.757 & 0.866 & 0.761 \\
\hline PL2 & 0.749 & 0.738 & 0.496 & 0.744 & 0.874 & 0.592 & 0.508 & 0.633 & 0.859 & 0.692 & 0.913 & 0.631 \\
\hline PL3 & 0.717 & 0.872 & 0.602 & 0.667 & 0.938 & 0.637 & 0.574 & 0.623 & 0.976 & 0.856 & 0.836 & 0.763 \\
\hline RE1 & 0.515 & 0.578 & 0.594 & 0.571 & 0.468 & 0.796 & 0.565 & 0.419 & 0.457 & 0.551 & 0.483 & 0.603 \\
\hline RE2 & 0.665 & 0.846 & 0.767 & 0.608 & 0.678 & 0.889 & 0.842 & 0.592 & 0.678 & 0.904 & 0.653 & 0.790 \\
\hline RE3 & 0.406 & 0.565 & 0.655 & 0.409 & 0.479 & 0.779 & 0.796 & 0.389 & 0.473 & 0.668 & 0.473 & 0.607 \\
\hline SAT1 & 0.511 & 0.673 & 0.630 & 0.468 & 0.518 & 0.758 & 0.807 & 0.449 & 0.503 & 0.723 & 0.499 & 0.647 \\
\hline SAT2 & 0.517 & 0.718 & 0.761 & 0.497 & 0.602 & 0.827 & 0.903 & 0.487 & 0.594 & 0.843 & 0.598 & 0.738 \\
\hline SAT3 & 0.414 & 0.574 & 0.886 & 0.383 & 0.434 & 0.735 & 0.882 & 0.413 & 0.43 & 0.674 & 0.419 & 0.732 \\
\hline SE1 & 0.607 & 0.485 & 0.388 & 0.621 & 0.465 & 0.502 & 0.432 & 0.839 & 0.458 & 0.480 & 0.509 & 0.408 \\
\hline SE2 & 0.593 & 0.487 & 0.341 & 0.531 & 0.504 & 0.443 & 0.412 & 0.858 & 0.507 & 0.516 & 0.508 & 0.397 \\
\hline SE3 & 0.871 & 0.662 & 0.449 & 0.753 & 0.714 & 0.519 & 0.471 & 0.850 & 0.696 & 0.630 & 0.736 & 0.569 \\
\hline SI1 & 0.749 & 0.738 & 0.496 & 0.744 & 0.874 & 0.592 & 0.508 & 0.633 & 0.859 & 0.692 & 0.913 & 0.631 \\
\hline SI2 & 0.717 & 0.872 & 0.602 & 0.667 & 0.938 & 0.637 & 0.574 & 0.623 & 0.976 & 0.856 & 0.836 & 0.763 \\
\hline SI3 & 0.717 & 0.872 & 0.602 & 0.667 & 0.938 & 0.637 & 0.574 & 0.623 & 0.976 & 0.856 & 0.836 & 0.763 \\
\hline
\end{tabular}


Table 5. Cont.

\begin{tabular}{|c|c|c|c|c|c|c|c|c|c|c|c|c|}
\hline & AC & CRI & ES & FE & PL & RE & SAT & SE & SI & $S X$ & TH & TR \\
\hline SX1 & 0.665 & 0.846 & 0.767 & 0.608 & 0.678 & 0.889 & 0.842 & 0.592 & 0.678 & 0.904 & 0.653 & 0.79 \\
\hline SX2 & 0.717 & 0.872 & 0.602 & 0.667 & 0.938 & 0.637 & 0.574 & 0.623 & 0.976 & 0.856 & 0.836 & 0.763 \\
\hline SX3 & 0.427 & 0.608 & 0.650 & 0.411 & 0.502 & 0.702 & 0.811 & 0.406 & 0.482 & 0.782 & 0.498 & 0.624 \\
\hline TH1 & 0.780 & 0.717 & 0.544 & 0.777 & 0.785 & 0.592 & 0.516 & 0.666 & 0.775 & 0.687 & 0.910 & 0.670 \\
\hline TH2 & 0.703 & 0.771 & 0.535 & 0.641 & 0.916 & 0.596 & 0.551 & 0.589 & 0.824 & 0.757 & 0.866 & 0.761 \\
\hline TH3 & 0.749 & 0.738 & 0.496 & 0.744 & 0.874 & 0.592 & 0.508 & 0.633 & 0.859 & 0.692 & 0.913 & 0.631 \\
\hline TR1 & 0.502 & 0.721 & 0.939 & 0.495 & 0.597 & 0.759 & 0.780 & 0.395 & 0.593 & 0.750 & 0.566 & 0.931 \\
\hline TR2 & 0.568 & 0.716 & 0.932 & 0.538 & 0.609 & 0.769 & 0.780 & 0.482 & 0.63 & 0.752 & 0.614 & 0.909 \\
\hline TR3 & 0.703 & 0.771 & 0.535 & 0.641 & 0.916 & 0.596 & 0.551 & 0.589 & 0.824 & 0.757 & 0.866 & 0.761 \\
\hline
\end{tabular}

\subsection{Inner Model Verification}

In the phase of determining the results of the proposed hypothesis, the method used is to use the Path coefficient benchmark which is taken based on the value of $t$, after computing using bootstrapping. The proposed hypothesis is possibly accepted only if the $\mathrm{t}$ value is higher than 1.95. These concepts are all in the inner model, while the Table 6 details of the hypotheses that have been computed.

Table 6. Summary of hypotheses testing results.

\begin{tabular}{ccccc}
\hline Hypothesis & Path & $\begin{array}{c}\text { Standardized } \\
\text { Path Coefficient }\end{array}$ & t-Value & Conclusion \\
\hline H1 & CE-PV & $0.875^{* * *}$ & 36,443 & Accepted \\
H2 & CE-RQ & $0.209^{* * *}$ & 2570 & Accepted \\
H3 & CE-SI & 0.049 & 1190 & Rejected \\
H4 & PV-RQ & $0.360^{* * *}$ & 2169 & Accepted \\
H5 & PV-SI & $0.762^{* * *}$ & 15,601 & Accepted \\
H6 & RQ-SI & $0.729^{* * *}$ & 17,159 & Accepted \\
\hline Note: ${ }^{* * *} p$-value $<0.001$. & & & &
\end{tabular}

Table 6 and Figure 2 show that CE has an appreciative and notable effect on PV, supporting H1 (CE $\rightarrow$ PV: $=0.875$, $t$-value $=36,440)$. Deeper into the result of analysis, it shows that CE has a great effect on RQ since it supports H2 $(C E \rightarrow R Q:=0.209$, $t$-value $=2.570)$. However, CE does not significantly affect SI directly, which means that the H3 hypothesis is rejected $(\mathrm{CE} \rightarrow \mathrm{SI}:=0.049, \mathrm{t}$-value $=1.190)$. PV significantly and positively affects $R Q$, which supports H4 (PV $\rightarrow \mathrm{RQ}:=0.360$, $\mathrm{t}$-value $=2.169$ ). PV significantly and positively affects SI, which supports H5 (PV $\rightarrow$ SI: $=0.762$, t-value $=15.601)$. Finally, RQ significantly and positively affects SI, which supports $\mathrm{H} 6(\mathrm{RQ} \rightarrow \mathrm{SI}:=0.729$, $\mathrm{t}$-value $=17.159)$.

\subsection{Mediation Effects Verification}

In this study, we conducted a validation test on the mediation effect with the benchmark being path analysis, while the method used is the Sobel test; its function is to measure the impact and significance of variable $x$ on variable $y$ indirectly [122]. If it is seen from Table 7 which has been produced from the Sobel test, the $z$ value and $p$-value are determinants of whether these variables have an indirect impact. If the $z$ value on the mediator variable is more than 1.96, it means that the mediator variable is significant. 


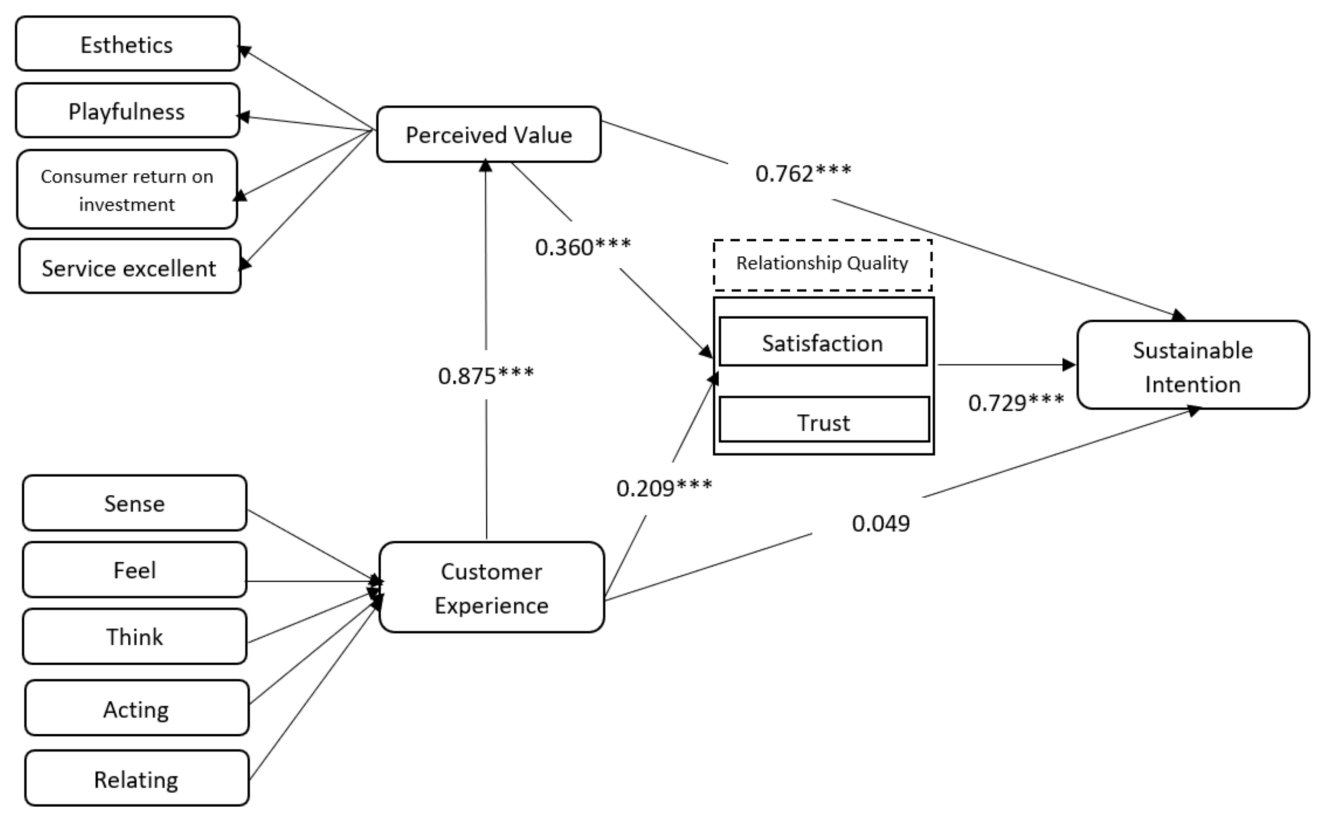

Figure 2. Inner model results. Note: ${ }^{* * *} p$-value $<0.001$.

Table 7. Mediation effects testing.

\begin{tabular}{cccc}
\hline Constructs & Construct Relationships & $\begin{array}{c}\text { T-Value of Path } \\
\text { Coefficients }\end{array}$ & Sobel Test's z-Value \\
\hline CE-PV-RQ & CE-PV & 36,443 & $2.165^{* *}$ \\
CE-RQ-SI & PV-RQ & 2169 & $2.541^{* *}$ \\
& CE-RQ & 2570 & $2.152^{* *}$ \\
PV-RQ-SI & RQ-SI & 17,159 & $15.524^{* * *}$ \\
& PV-RQ & 2169 & \\
CE-PV-SI & RQ-SI & 17,159 & \\
& CE-PV & 36,443 & 17,159 \\
\hline
\end{tabular}

Note: ${ }^{* *} p$-value $<0.01 ;{ }^{* * *} p$-value $<0.001$.

\section{Discussion}

This study focused on the integration of PV [123] and CE [84]. Then, both are combined with RQ as a factor or measuring tool that affects customer behavior on social media commerce. Good perceived value and good customer experience depend on the features facilitated by the provider on its social media [26]. The notable findings have been successfully obtained at the end of the analysis, both for academics and practitioners.

\subsection{Theoretical Implications}

This recently-finished study gives contribution to the literature of PV and CE. First, a holistic model of the antecedents is provided for customer behavioral outcomes derived from S-Commerce content marketing. Although S-Commerce has received attention from several researchers, a holistic model proposing the sustainability of attention in such a platform is still very lacking in availability. Second, this study specifically and simultaneously confirmed PV and CE against RQ in the context of S-Commerce. Although it is widely recognized by researchers that PV can cause RQ formation [18,123,124], as well as CE for RQ $[86,114,125]$, our study augments this study by integrating PV and CE in the framework for $\mathrm{RQ}$ for $\mathrm{S}$-Commerce. This study also confers a significant contribution to the associated literature by drawing a new data set on a survey to existing S-Commerce users. 


\subsection{Managerial Implications}

Another special contribution delivered by this recently finished study is allowing entrepreneurs and companies to use social media as a transaction medium. The study guides entrepreneurs to pay attention to the urgency of creating social media with content-based messages. It influences the results of customer behavior and leads to marketing goals.

Getting the test results of $\mathrm{H} 1$ and $\mathrm{H} 2$, it can be said that $\mathrm{CE}$ has a positive and significant effect on PV and RQ. On the other hand, the result of $\mathrm{H} 3$ indicates that CE indirectly affects SI, but SI is negotiated through RQ. Theoretically, CE is not just a conventional marketing method that only focuses on interactive experiences, emotional reactions, and customer interests. More than that, $\mathrm{CE}$ is the result of psychological evaluation after customers interact at S-Commerce, and in the end they produce preferences regarding the display and configuration of the S-Commerce environment. So, if S-Commerce can attract customer satisfaction and trust, then the customer will feel more attached to the service, resulting in a positive effect. When this effect is generated, the S-Commerce provider can then benefit from S-Commerce sustainability or promotion. On the other hand, the provider should try to develop an interesting narrative about the related product to leave an impression and influence for the long term.

Based on Hypothesis 2, the test found that CE has a significant effect on RQ so that for providers as content managers at S-Commerce, they must first create content with interesting narration, back sound, design, layout, or other things of an interesting or other entertaining nature with the primary purpose of generating feelings of happiness, joy, or entertainment for subscribers after viewing the content [126]. Second, creating interactive content between customers and providers is an important factor; for example on Instagram, TikTok, and Facebook media, providers must actively answer questions from customers, and this can establish two-way direct communication between customers and providers.

Third, in terms of providing content, the provider must be trusted, the content displayed is a physical representation of the product, the content must be relevant to the product, and the company as a provider must show absolute truth. In addition, data and information from the content must be up-to-date, relevant to the current situation, such as promos on certain special days and dates. Fourth, in posting content, providers must pay attention to the right time, hashtag, and layout. For example, in posting content, the posting time must pay attention to prime time which is usually viewed by customers. In addition, informative graphic design can make it easier for customers to understand the information in a short time [127]. Next, content created for marketing must be communicative and informative, which can encourage customers to voluntarily share the content on other social media or groups they follow, rewards can be used to attract them to actively participate in sharing the content. These strategies, in addition to increasing the number of customer participation, can also improve the quality of the relationship between the two.

In this study, we found that the CE variable has an enormous impact on RQ. CE is a variable that can be a reference in building marketing content, especially in s-commerce; this is in line with hypothesis 2 . If viewed from the aspect of CE, digital content cannot reach the three aspects that exist in $\mathrm{CE}$, namely the sense of taste, smell, and touch; all these aspects can only be represented by two other aspects of $\mathrm{CE}$, namely the senses of sight and hearing. So, content creators must be able to ensure that both aspects of $\mathrm{CE}$ can represent the shortcomings of the previous three aspects. Remembering research conducted by Hultén et al. [128], the content creator's ability to build and present the displayed content is a description that can represent the weakness of the item variable in $\mathrm{CE}$, which represents the sense of taste, touch, and smell. So graphic design skills become dominant. Viewed from the emotional aspect, marketing content can become an integral part of s-commerce; when the content has reached the emotional aspect, it has an impact on their understanding of the message they want to convey from the provider. If the customer can digest the message conveyed through the content properly, then the goal that the provider wants to convey will be achieved. With the involvement of the CE variable in the s-commerce 
concept, it is possible to create harmony and develop the quality of relationships between both parties.

Furthermore, based on several previous studies, the management of digital content in s-commerce that refers to the PV and CE variables can create customer relationship quality, and this can also affect customer perceptions. In the field of marketing science, the quality of the relationship between customers and providers is the main goal that must be achieved properly [87]; if these efforts are fulfilled it will have an impact on minimizing the marketing budget [129]. This study confirms that the concept of customer relationship quality can significantly provide added value in building good relationships between customers and providers. This is in line with hypotheses 3-5 that we proposed earlier. The impact of a good customer relationship will result in sustainable customer intention in s-commerce. Furthermore, digitalization causes social media to have a major role in the distribution of information, especially regarding the value of a product. So, it must be considered in detail the quality of digital content in marketing on s-commerce, to have optimal and targeted performance for the sustainability of product and company values. Another aspect that must be considered in s-commerce is the value of a product and brand image, both of which must have the right correlation with performance and good marketing so that the experience felt by the customer is positive [130-133]. On the other hand, from the indirect correlation aspect, customer relationship quality has the power to encourage engagement between customers and providers in strengthening the value of a brand. Benefits that can be felt when customer relationship quality increases is a favorable customer relationship and by itself will increase loyalty to the products offered.

In this study, we conclude that the PV concept for s-commerce users has a significant correlation to RQ and SI, it shows that hypotheses 4 and 5 are acceptable. The correlation between the customer and the provider can practically form a strong bond between the two, especially if applied to s-commerce, the relationship is emotionally intertwined that will last for a long time. The PV concept is a motor in strengthening and increasing customer satisfaction and trust which is extracted in the variable relationship quality, this will provide a pleasant experience for customers in s-commerce activities, so that CE, PV, and RQ are an integral part in forming SI in business a long period.

\section{Conclusions and Future Work}

With the digitalization era, especially the high use of social media commerce, the demands for the creation of commercially valuable content are a must that must be met by providers. However, providers should not only focus on content that has marketing value, but more than that, communication and social interaction aspects between buyers and sellers must be the main thing. In the aspect of utilizing s-commerce, the concepts of PV and $\mathrm{CE}$ are parameters that can be used as benchmarks to determine the extent of customer sustainability intentions. Content creators must have good intuition and experience, to build creativity in terms of building marketing content that is under aspects of current customer needs, so that it is right on target. With the right marketing content in line with user needs, a positive impact on the relationship quality between the two is built, which will ultimately result in SI being achieved.

In general, this research has been carried out based on comprehensive concepts and methodologies, meticulous state-of-the-art data collection and data sorting, and highquality data analysis, but several things can be done by the next researcher for wider development. For example, in this study we did not conduct a comparative study of various existing social media, so this section can be carried out by future researchers by conducting comparative studies on s-commerce platforms to produce more inclusive conclusions. Second, this research does not conduct an assessment of users in global scope, which means that bias may occur, because in certain countries it is possible to have differences specific to certain platforms; for example, people in Indonesia tend to use Instagram and Facebook, while in Taiwan they generally use Lines, and so on. Third, subsequent research can integrate several concepts such as the expectation confirmation 
model [131,134-136], with the concepts of CE and PV on customer sustainable intention in scommerce. Fourth, future research can examine customer interaction and the collaborative concept of society $[93,137,138]$. Of course, this concept can be created with customer relationship management (CRM), and then the CRM can be correlated with s-commerce.

Author Contributions: Conceptualization, U.R. and T.H. (Taqwa Hariguna); methodology, T.H. (Tanaporn Hongsuchon); software, T.H. (Tanaporn Hongsuchon); validation, T.H. (Tanaporn Hongsuchon), A.R. and U.R.; formal analysis, T.H. (Taqwa Hariguna); investigation, T.H. (Taqwa Hariguna); resources, A.R.; data curation, U.R.; writing original draft preparation, T.H. (Taqwa Hariguna); writing—-review and editing, A.R.; visualization, T.H. (Tanaporn Hongsuchon); supervision, A.R.; project administration, U.R.; funding acquisition, A.R. All authors have read and agreed to the published version of the manuscript.

Funding: This research received no external funding.

Institutional Review Board Statement: Ethical review and approval was not required for this study on human participants in accordance with the local legislation and institutional requirements.

Informed Consent Statement: Written informed consent from the patients/participants was not required to participate in this study in accordance with the national legislation and the institutional requirements.

Data Availability Statement: The raw data supporting the conclusions of this article will be made available by the authors, without undue reservation, to any qualified researchers.

Conflicts of Interest: The authors declare no conflict of interest.

\section{References}

1. Lin, C.P. Learning virtual community loyalty behavior from a perspective of social cognitive theory. Int. J. Hum. Comput. Interact. 2010, 26, 345-360. [CrossRef]

2. O'Reilly, T. What is web 2.0. In Design Patterns and Business Models for the Next Generation of Software; O'Reilly Media, Inc: Sebastopol, CA, USA, 2005.

3. Cachia, R.; Compañó, R.; Da Costa, O. Grasping the potential of online social networks for foresight. Technol. Forecast. Soc. Chang. 2007, 74, 1179-1203. [CrossRef]

4. Chen, S.C.; Yen, D.C.; Hwang, M.I. Factors influencing the continuance intention to the usage of Web 2.0: An empirical study. Comput. Hum. Behav. 2012, 28, 933-941. [CrossRef]

5. Huang, Z.; Benyoucef, M. User preferences of social features on social commerce websites: An empirical study. Technol. Forecast. Soc. Chang. 2015, 95, 55-72. [CrossRef]

6. Hariguna, T. An empirical study to understanding students continuance intention use of multimedia online learning. Int. J. Appl. Info. M. 2021, 1, 42-52. [CrossRef]

7. Yi, M.; Oh, S.G.; Kim, S. Comparison of social media use for the US and the Korean governments. Gov. Inf. Q. 2013, 30, 310-317. [CrossRef]

8. Cheng, T.H.; Shih-Chih Chen, S.C.; Hariguna, T. The empirical study of usability and credibility on intention usage of governmentto-citizen services. J. Appl. Data. Sciences. 2021, 2, 36-44. [CrossRef]

9. Algesheimer, R.; Dholakia, U.M.; Hermann, A. The social influence of brand community: Evidence from European car clubs. J. Mark. 2005, 69, 19-34. [CrossRef]

10. Tsaur, S.H.; Chiu, Y.T.; Wang, C.H. The visitors behavioral consequences of experiential marketing: An empirical study on Taipei Zoo. J. Travel Tour. Mark. 2007, 21, 47-64. [CrossRef]

11. von Wallpach, S.; Kreuzer, M. Multi-sensory sculpting (MSS): Eliciting embodied brand knowledge via multi-sensory metaphors. J. Bus. Res. 2013, 66, 1325-1331. [CrossRef]

12. Kim, D.; Perdue, R.R. The effects of cognitive, affective, and sensory attributes on hotel choice. Int. J. Hosp. Manag. 2013, 35, 246-257. [CrossRef]

13. Bruhn, M.; Schnebelen, S.; Schäfer, D. Antecedents and consequences of the quality of e-customer-to-customer interactions in B2B brand communities. Ind. Mark. Manag. 2014, 43, 164-176. [CrossRef]

14. Shobeiri, S.; Laroche, M.; Mazaheri, E. Shaping e-retailer's website personality: The importance of experiential marketing. J. Retail. Consum. Serv. 2013, 20, 102-110. [CrossRef]

15. Xiang, Z.; Gretzel, U. Role of social media in online travel information search. Tour. Manag. 2010, 31, 179-188. [CrossRef]

16. Mazman, S.G.; Usluel, Y.K. Modeling educational usage of Facebook. Comput. Educ. 2010, 55, 444-453. [CrossRef]

17. Chou, S.W.; Min, H.T.; Chang, Y.C.; Lin, C.T. Understanding continuance intention of knowledge creation using extended expectation-confirmation theory: An empirical study of Taiwan and China online communities. Behav. Inform. Technol. 2010, 29, 557-570. [CrossRef] 
18. Kim, A.J.; Ko, E. Do social media marketing activities enhance customer equity? An empirical study of luxury fashion brand. J. Bus. Res. 2012, 65, 1480-1486. [CrossRef]

19. Kushin, M.J.; Yamamoto, M. Did social media really matter? College students' use of online media and political decision making in the 2008 election. Mass Commun. Soc. 2010, 13, 608-630. [CrossRef]

20. Pookulangara, S.; Koesler, K. Cultural influence on consumers usage of social networks and its impact on online purchase intentions. J. Retail. Consum. Serv. 2011, 18, 348-354. [CrossRef]

21. Chang, C.C.; Hung, S.W.; Cheng, M.J.; Wu, C.Y. Exploring the intention to continue using social networking sites: The case of Facebook. Technol. Forecast. Soc. Chang. 2015, 95, 48-56. [CrossRef]

22. Lin, K.Y.; Lu, H.P. Intention to continue using Facebook fan pages from the perspective of social capital theory. Cyberpsychol. Behav. Soc. Netw. 2011, 14, 565-570. [CrossRef]

23. Khalifa, A.S. Customer value: A review of recent literature and an integrative configuration. Manag. Decis. 2004, 42, 645-666. [CrossRef]

24. Heskett, J.L.; Jones, T.O.; Loveman, G.W.; Sasser, W.E.; Schlesinger, L.A. Putting the service-profit chain to work. Harv. Bus. Rev. 1994, 72, 164-174.

25. Ravald, A.; Gronroos, C. The value concept and relationship marketing. Eur. J. Mark. 1996, 30, 19-30. [CrossRef]

26. Yu, J.; Zo, H.; Kee Choi, M.; Ciganek, P.A. User acceptance of location-based social networking services: An extended perspective of perceived value. Online Inf. Rev. 2013, 37, 711-730. [CrossRef]

27. Zeithaml, V.A. Consumer perceptions of price, quality and value: A means-end model and synthesis of evidence. J. Mark. 1988, 52, 2-22. [CrossRef]

28. Lovelock, C.H. Services Marketing, 4th ed.; Prentice Hall Internationa: Hoboken, NJ, USA, 2001.

29. Kim, H.W.; Chan, H.C.; Gupta, S. Value-based adoption of mobile Internet: An empirical investigation. Decis. Support Syst. 2007, 43, 111-126. [CrossRef]

30. Butz, H.E., Jr.; Goodstein, L.D. Measuring customer value: Gaining the strategic advantage. Organ. Dyn. 1997, $24,63-77$. [CrossRef]

31. Grönroos, C. Service logic revisited: Who creates value? And who co-creates? Eur. Bus. Rev. 2008, 20, 298-314. [CrossRef]

32. Lai, A.W. Consumer values, product benefits and customer value: A consumption behavior approach. Adv. Consum. Res. 1995, 22, 381-388.

33. Sheth, J.N.; Newman, B.I.; Gross, B.L. Why we buy what we buy: A theory of consumption values. J. Bus. Res. 1991, 22, 159-170. [CrossRef]

34. Sweeney, J.C.; Soutar, G.N. Consumer perceived value: The development of a multiple item scale. J. Retail. 2001, 77, 203-220. [CrossRef]

35. Ledden, L.; Kalafatis, S.P.; Samouel, P. The relationship between personal values and perceived value of education. J. Bus. Res. 2007, 60, 965-974. [CrossRef]

36. Tynan, C.; McKechnie, S.; Chhuon, C. Co-creating value for luxury brands. J. Bus. Res. 2010, 63, 1156-1163. [CrossRef]

37. Sirdeshmukh, D.; Singh, J.; Sabol, B. Consumer trust, value, and loyalty in relational exchanges. J. Mark. 2002, 66, 15-37. [CrossRef]

38. Wittmer, A.; Rowley, E. Customer value of purchasable supplementary services: The case of a European full network carrier's economy class. J. Air Transp. Manag. 2014, 34, 17-23. [CrossRef]

39. Mathwick, C.; Malhotra, N.; Rigdon, E. Experiential value: Conceptualization, measurement and application in the catalog and Internet shopping environment. J. Retail. 2001, 77, 39-56. [CrossRef]

40. Vera, J.; Trujillo, A. Service quality dimensions and superior customer perceived value in retail banks: An empirical study on Mexican consumers. J. Retail. Consum. Serv. 2013, 20, 579-586. [CrossRef]

41. Holbrook, M.B. The nature of customer value: An axiology of services in the consumption experience. In Service Quality: New Directions in Theory and Practice; Rust, R.T., Oliver, R.L., Eds.; Sage: Newbury Park, CA, USA, 1994; pp. $21-71$.

42. Ryu, K.; Han, H.; Jang, S.S. Relationships among hedonic and utilitarian values, satisfaction and behavioral intentions in the fast-casual restaurant industry. Int. J. Contemp. Hosp. Manag. 2010, 22, 416-432. [CrossRef]

43. Hosany, S.; Witham, M. Dimensions of cruisers experiences, satisfaction, and intention to recommend. J. Travel Res. 2010, 49, 351-364. [CrossRef]

44. De Nisco, A.; Warnaby, G. Urban design and tenant variety influences on consumers' emotions and approach behavior. J. Bus. Res. 2014, 67, 211-217. [CrossRef]

45. Horng, J.S.; Chou, S.F.; Liu, C.H.; Tsai, C.Y. Creativity, aesthetics and eco-friendliness: A physical dining environment design synthetic assessment model of innovative restaurants. Tour. Manag. 2013, 36, 15-25. [CrossRef]

46. Kang, J.; Tang, L.; Fiore, A.M. Enhancing consumer-Brand relationships on restaurant Facebook fan pages: Maximizing consumer benefits and increasing active participation. Int. J. Hosp. Manag. 2014, 36, 145-155. [CrossRef]

47. Huang, C.Y.; Chou, C.J.; Lin, P.C. Involvement theory in constructing bloggers intention to purchase travel products. Tour. Manag. 2010, 31, 513-526. [CrossRef]

48. Calver, S.J.; Page, S.J. Enlightened hedonism: Exploring the relationship of service value, visitor knowledge and interest, to visitor enjoyment at heritage attractions. Tour. Manag. 2013, 39, 23-36. [CrossRef] 
49. Schmitt, B.H. Experiential Marketing: How to Get Customers to Sense, Feel, Think, Act and Relate to Your Company and Brand; The Free Press: New York, NY, USA, 1999; Volume 14, pp. 275-277.

50. Pine, B.J.; Gilmore, J.H. Welcome to the experience economy. Harv. Bus. Rev. 1998, 76, 97-105.

51. Kao, Y.F.; Huang, L.S.; Yang, M.H. Effects of experiential elements on experiential satisfaction and loyalty intentions: A case study of the super basketball league in Taiwan. Int. J. Revenue Manag. 2007, 1, 79-96. [CrossRef]

52. Schmitt, B.H. The consumer psychology of brands. J. Consum. Psychol. 2012, 22, 7-17. [CrossRef]

53. Mason, M.C.; Paggiaro, A. Investigating the role of festival scape in culinary tourism: The case of food and wine events. Tour. Manag. 2012, 33, 1329-1336. [CrossRef]

54. Crosby, L.A.; Evans, K.R.; Cowles, D. Relationship quality in services selling: An Interpersonal influence perspective. J. Mark. 1990, 54, 68-81. [CrossRef]

55. Palmatier, R.W.; Dant, R.P.; Grewal, D.; Evans, K.R. Factors influencing the effectiveness of relationship marketing: A metaanalysis. J. Mark. 2006, 70, 136-153. [CrossRef]

56. Tajvidi, M.; Richard, M.-O.; Wang, Y.; Hajli, N. Brand co-creation through social commerce information sharing: The role of social media. J. Bus. Res. 2018, 121, 1-11. [CrossRef]

57. Anastasiei, B.; Dospinescu, N. Facebook advertising, relationship between types of message, brand attitude and perceived buying risk. Ann. Econ. Ser. 2017, 6, 18-26.

58. Bejou, D.; Wray, B.; Ingram, T.N. Determinants of relationship quality: An artificial neural network analysis. J. Bus. Res. 1996, 36, 137-143. [CrossRef]

59. Giovanis, A.; Athanasopoulou, P.; Tsoukatos, E. The role of service fairness in the service quality-Relationship quality-Customer loyalty chain: An empirical study. J. Serv. Theory Pract. 2015, 25, 744-776. [CrossRef]

60. Chen, C.-C.; Chang, Y.-C. What drives purchase intention on Airbnb? Perspectives of consumer reviews, information quality, and media richness. Telemat. Inform. 2018, 35, 1512-1523. [CrossRef]

61. Oliveira, T.; Alhinho, M.; Rita, P.; Dhillon, G. Modelling and testing consumer trust dimensions in e-commerce. Comput. Hum. Behav. 2017, 71, 153-164. [CrossRef]

62. Hajli, M.N. The role of social support on relationship quality and social commerce. Technol. Forecast. Soc. Chang. 2014, 87, 17-27. [CrossRef]

63. Garbarino, E.; Johnson, M.S. The different roles of satisfaction, trust, and commitment in customer relationships. J. Mark. 1999, 63, 70-87. [CrossRef]

64. Rajaobelina, L.; Bergeron, J. Antecedents and consequences of buyer-seller relationship quality in the financial services industry. Int. J. Bank Mark. 2009, 27, 359-380. [CrossRef]

65. Hsu, C.-L.; Chen, M.-C.; Kikuchi, K.; Machida, I. Elucidating the determinants of purchase intention toward social shopping sites: A comparative study of Taiwan and Japan. Telemat. Inform. 2017, 34, 326-338. [CrossRef]

66. Chen, S.-C.; Liu, S.-C.; Li, S.-H.; Yen, D.C. Understanding the mediating effects of relationship quality on technology acceptance: An empirical study of E-appointment system. J. Med. Syst. 2013, 37, 9981. [CrossRef]

67. Chen, S.-C.; Jong, D.; Lai, M.-T. Assessing the relationship between technology readiness and continuance intention in an e-appointment system: Relationship quality as a mediator. Med. Syst. 2014, 38, 76. [CrossRef]

68. Kim, W.G.; Lee, Y.-K.; Yoo, Y.-J. Predictors of Relationship quality and relationship outcomes in luxury restaurants. J. Hosp. Tour. Res. 2006, 30, 143-169. [CrossRef]

69. Liu, C.-T.; Guo, Y.M.; Lee, C.-H. The effects of relationship quality and switching barriers on customer loyalty. Int. J. Inf. Manag. 2011, 31, 71-79. [CrossRef]

70. Boles, J.S.; Johnson, J.T.; Barksdale, H.C. How salespeople build quality relationships: A replication and extension. J. Bus. Res. 2000, 48, 75-81. [CrossRef]

71. Jap, S.D.; Manolis, C.; Weitz, B.A. Relationship quality and buyer-seller interactions in channels of distribution. J. Bus. Res. 1999, 46, 303-313. [CrossRef]

72. Holmlund, M. A definition, model, and empirical analysis of business-to-business relationship quality. Int. J. Serv. Ind. Manag. 2008, 19, 32-62. [CrossRef]

73. Yadav, M.; Rahman, Z. The influence of social media marketing activities on customer loyalty: A study of e-commerce industry. Benchmarking 2018, 25, 3882-3905. [CrossRef]

74. Masri, N.W.; You, J.-J.; Ruangkanjanases, A.; Chen, S.-C.; Pan, C.-I. Assessing the effects of information system quality and relationship quality on continuance intention in e-tourism. Int. J. Environ. Res. Public Health 2020, 17, 174. [CrossRef] [PubMed]

75. Zhang, K.Z.; Benyoucef, M.; Zhao, S.J. Building brand loyalty in social commerce: The case of brand microblogs. Electron. Commer. Res. Appl. 2016, 15, 14-25. [CrossRef]

76. Founier, S. Consumers and their brands: Developing relationship theory in consumer research. J. Consum. Res. 1998, 24, 343-373. [CrossRef]

77. Dall'Olmo Riley, F.; De Chernatony, L. The service brand as relationships builder. Br. J. Manag. 2000, 11, 137-150. [CrossRef]

78. Veloutsou, C. Identifying the dimensions of the product-brand and consumer relationship. J. Mark. Manag. 2007, 23, 7-26. [CrossRef]

79. Pawle, J.; Cooper, P. Measuring emotion-lovemarks, the future beyond brands. J. Advert. Res. 2006, 46, 38-48. [CrossRef] 
80. Veloutsou, C.; Moutinho, L. Brand relationships through brand reputation and brand tribalism. J. Bus. Res. 2009, 62, 314-322. [CrossRef]

81. Dacin, P.A.; Smith, D.C. The effect of brand portfolio characteristics on consumer evaluations of brand extensions. J. Mark. Res. 1994, 229-242. [CrossRef]

82. Morgan-Thomas, A.; Veloutsou, C. Beyond technology acceptance: Brand relationships and online brand experience. J. Bus. Res. 2013, 66, 21-27. [CrossRef]

83. Pradana, M.G.; Ha, H.T. Maximizing strategy improvement in mall customer segmentation using k-means clustering. J. Appl. Data. Sci. 2021, 2, 19-25. [CrossRef]

84. Schmitt, B. Experiential marketing. J. Mark. Manag. 1999, 15, 53-67. [CrossRef]

85. Homburg, C.; Jozi 'c, D.; Kuehnl, C. Customer experience management: Toward implementing an evolving marketing concept. J. Acad. Mark. Sci. 2017, 45, 377-401. [CrossRef]

86. Chen, S.-C.; Lin, C.-P. The impact of customer experience and perceived value on sustainable social relationship in blogs: An empirical study. Technol. Forecast. Soc. Chang. 2015, 96, 40-50. [CrossRef]

87. Tajvidi, M.; Wang, Y.; Hajli, N.; Love, P.E. Brand value Co-creation in social commerce: The role of interactivity, social support, and relationship quality. Comput. Hum. Behav. 2017, 115, 105238. [CrossRef]

88. Bhattacherjee, A. Understanding information systems continuance: An expectation confirmation model. MIS Q. 2001, 25, 351-370. [CrossRef]

89. Bhattacherjee, A.; Perols, J.; Sanford, C. Information technology continuance: A theoretical extension and empirical test. J. Comput. Inf. Syst. 2008, 49, 17-26. [CrossRef]

90. Chen, S.C.; Liu, M.L.; Lin, C.P. Integrating technology readiness into the expectation confirmation model: An empirical study of mobile services. Cyberpsychol. Behav. Soc. Netw. 2013, 16, 604-612. [CrossRef]

91. Kim, H.R. Developing an index of online customer satisfaction. J. Financ. Serv. Mark. 2005, 10, 49-64. [CrossRef]

92. Janda, S.; Ybarra, A. Do product and consumer characteristics affect the relationship between online experience and customer satisfaction? J. Internet Commer. 2005, 4, 133-151. [CrossRef]

93. Torres, E.N.; Fu, X.; Lehto, X. Examining key drivers of customer delight in a hotel experience: A cross-cultural perspective. Int. J. Hosp. Manag. 2014, 36, 255-262. [CrossRef]

94. Christodoulides, G.; De Chernatony, L.; Furrer, O.; Shiu, E.; Abimbola, T. Conceptualising and measuring the equity of online brands. J.Mark. Manag. 2006, 22, 799-825. [CrossRef]

95. Koufaris, M. Applying the technology acceptance model and flow theory to online consumer behavior. Inf. Syst. Res. 2002, 13, 205-223. [CrossRef]

96. Brakus, J.J.; Schmitt, B.H.; Zarantonello, L. Brand experience: What is it? How is it measured? Does it affect loyalty? J. Mark. 2009, 73, 52-68. [CrossRef]

97. Luo, M.M.; Chen, J.S.; Ching, R.K.; Liu, C.C. An examination of the effects of virtual experiential marketing on online customer intentions and loyalty. Serv. Ind. J. 2011, 31, 2163-2191. [CrossRef]

98. Cronin, J.J.; Brady, M.K.; Hult, G.T.M. Assessing the effects of quality, value and customer satisfaction on consumer behavioral intentions in service environments. J. Retail. 2000, 76, 193-218. [CrossRef]

99. Chen, C.F.; Chen, F.S. Experience quality, perceived value, satisfaction and behavioral intentions for heritage tourists. Tour. Manag. 2010, 31, 29-35. [CrossRef]

100. Oh, H. Service quality, customer satisfaction, and customer value: A holistic perspective. Int. J. Hosp. Manag. 1999, 18, 67-82. [CrossRef]

101. Yang, Z.; Peterson, R.T. Customer perceived value, satisfaction, and loyalty: The role of switching costs. Psychol. Mark. 2004, 21, 799-822. [CrossRef]

102. Lin, T.C.; Wu, S.; Hsu, J.S.C.; Chou, Y.C. The integration of value-based adoption and expectation-confirmation models: An example of IPTV continuance intention. Decis. Support. Syst. 2012, 54, 63-75. [CrossRef]

103. Oliver, R.L. A cognitive model of the antecedents and consequences of satisfaction decisions. J. Mark. Res. 1980, 17, 460-469. [CrossRef]

104. Hong, S.; Thong, J.Y.; Tam, K.Y. Understanding continued information technology usage behavior: A comparison of three models in the context of mobile internet. Decis. Support Syst. 2006, 42, 1819-1834. [CrossRef]

105. Thong, J.Y.; Hong, S.J.; Tam, K.Y. The effects of post-adoption beliefs on the expectation-confirmation model for information technology continuance. Int. J. Hum. Comput. Stud. 2006, 64, 799-810. [CrossRef]

106. Kollmann, T.; Suckow, C. Sustaining the brand idea in electronic environments. Int. J. Bus. Environ. 2008, 2, 153-167. [CrossRef]

107. Choi, Y.; Gao, D. The role of intermediation in the governance of sustainable Chinese web marketing. Sustainability 2014, 6, 4102-4118. [CrossRef]

108. Digital 2020—We Are Social. Available online: https:/ / wearesocial.com/digital-2020 (accessed on 3 July 2021).

109. Churchill, G.A.; Peter, J.P. Research design effects on the reliability of rating scales: A meta-analysis. J. Mark. Res. 1984, 21, 360. [CrossRef]

110. Anderson, J.C.; Gerbing, D.W. Structural equation modeling in practice: A review and recommended two-step approach. Psychol. Bull. 1988, 103, 411-423. [CrossRef] 
111. Petter, S.; Straub, D.; Rai, A. Specifying Formative Constructs in Information Systems Research 2007. Available online: https: / / scholarworks.gsu.edu/cis_facpubhttp:/ / misq.org/ (accessed on 1 July 2021).

112. Chin, W.W.; Newsted, P.R. Structural equation modeling analysis with small samples using partial least squares. Stat. Strateg. Small Sample Res. 1999, 1, 307-341.

113. Majchrzak, A.; Malhotra, A.; John, R. Perceived individual collaboration know-how development through information technologyenabled contextualization: Evidence from distributed teams. Inf. Syst. Res. 2005, 16, 9-27. [CrossRef]

114. Rajaobelina, L. The Impact of customer experience on relationship quality with travel agencies in a multichannel environment. J. Travel Res. 2017, 57, 206-217. [CrossRef]

115. Urbach, N.; Ahlemann, F. Structural equation modeling in information systems research using partial least squares. J. Inf. Technol. Theory Appl. 2010, 11, 5-40.

116. Hair, J.F.; Ringle, C.M.; Sarstedt, M. PLS-SEM: Indeed a silver bullet. J. Mark. Theory Pract. 2011, 19, 139-152. [CrossRef]

117. Hsu, H.Y.; Tsou, H.-T. Understanding customer experiences in online blog environments. Int. J. Inf. Manag. 2011, 31, 510-523. [CrossRef]

118. Bonsón, E.; Carvajal-Trujillo, E.; Escobar-Rodríguez, T. Influence of trust and perceived value on the intention to purchase travel online: Integrating the effects of assurance on trust antecedents. Tour. Manag. 2015, 47, 286-302. [CrossRef]

119. Lu, B.; Fan, W.; Zhou, M. Social presence, trust, and social commerce purchase intention: An empirical research. Comput. Hum. Behav. 2016, 56, 225-237. [CrossRef]

120. Fornell, C.; Larcker, D.F. Evaluating structural equation models with unobservable variables and measurement error. J. Mark. Res. 1981, 18, 39-50. [CrossRef]

121. Hair, J.F., Jr.; Hult, G.T.M.; Ringle, C.; Sarstedt, M. A Primer on Partial Least Squares Structural Equation Modeling (PLS-SEM); Sage: Los Angeles, CA, USA, 2016.

122. Sobel, M.E. Asymptotic confidence intervals for indirect effects in structural equation models. Sociol. Methods Res. 1982, 13, 290-312. [CrossRef]

123. Chen, S.-C.; Lin, C.-P. Understanding the effect of social media marketing activities: The mediation of social identification, perceived value, and satisfaction. Technol. Forecast. Soc. Chang. 2019, 140, 22-32. [CrossRef]

124. Seo, E.-J.; Park, J.-W. A study on the effects of social media marketing activities on brand equity and customer response in the airline industry. J. Air Transp. Manag. 2018, 66, 36-41. [CrossRef]

125. Lemon, K.N.; Verhoef, P.C. Understanding customer experience throughout the customer journey. J. Mark. 2016, 80, 69-96. [CrossRef]

126. Krishna, A. Customer Sense: How the 5 Senses Influence Buying Behavior; Palgrave Macmillan: London, UK, 2013.

127. Shin, J.; Chae, H.; Ko, E. The power of e-WOM using the hashtag: Focusing on SNS advertising of SPA brands. Int. J. Advert. 2018, 37, 71-85. [CrossRef]

128. Hultén, B.; Broweus, N.; van Dijk, M. What is sensory marketing? In Sensory Marketing; Palgrave Macmillan: London, UK, 2009; pp. 1-23.

129. Tsai, H.-T.; Huang, H.-C. Determinants of e-repurchase intentions: An integrative model of quadruple retention drivers. Inf. Manag. 2007, 44, 231-239. [CrossRef]

130. Anastasiei, B.; Dospinescu, N. A model of the relationships between the Big Five personality traits and the motivations to deliver word-of-mouth online. Psihologija 2018, 51, 215-227. [CrossRef]

131. Dospinescu, O.; Percă-Robu, A.E. The analysis of e-commerce sites with eye-tracking technologies. BRAIN. Broad Res. Artif. Intell. Neurosci. 2017, 8, 85-100.

132. Baird, C.H.; Parasnis, G. From social media to social customer relationship management. Strategy Leadersh. $2011,39,30-37$. [CrossRef]

133. Magalhães, M.; Pereira, M.S.; Lobo, C.C.; Cardoso, A.; D’Orey, F.; Ferreira, T.S. Data mining ppv an applied deep leaning neuromarketing tool to the performance of the point of sale promotion: A quantitative study. Acad. Strateg. Manag. J. 2021, $20,1-11$.

134. Sadiartha, A.A.N.G.; Suartina, I.W. The role of the influence of satisfaction measurement through CRM (customer relationship marketing) towards consumer confidence in Elite Sang Tunas kid courses denpasar. Int. Rev. Commun. Mark. Mix. 2021, 1, 23-29.

135. Gutama, D.; Umami, I.; Saputro, P. Analysis of the effect of website sales quality on purchasing decisions on e-commerce websites. Int. J. Inform. Inf. Syst. 2021, 4, 71-81. [CrossRef]

136. Prabowo, N.; Pujiarto, B.; Wijaya, F.; Gita, L.; Alfandy, D. Social network analysis for user interaction analysis on social media regarding e-commerce business. Int. J. Inform. Inf. Syst. 2021, 4, 95-102. [CrossRef]

137. Herrando, C.; Jiménez-Martínez, J.; De Hoyos, M. Boosting Purchase intention and online participation through passion. Int. J. Inform. Inf. Syst. 2020, 3, 136-145. [CrossRef]

138. Chen, Y.; Huang, T.; Hung, S. The charisma of online group-buying: The Moderating role of social motivation. Int. J. Inform. Inf. Syst. 2021, 2, 99-101. [CrossRef] 